Egyptian Journal of Aquatic Biology \& Fisheries

Zoology Department, Faculty of Science,

Ain Shams University, Cairo, Egypt.

ISSN $1110-6131$

Vol. 25(1): $681-697$ (2021)

www.ejabf.journals.ekb.eg

\title{
Status of Indo-Pacific Bottlenose Dolphin, Tursiops aduncus (Family Delphinidae: Order Cetacea) in the Northern Protected Islands, Hurghada, Red Sea, Egypt
}

\author{
Aldoushy Mahdy ${ }^{1 *}$, Ahmed Ghallab ${ }^{2}$, Hashem Madkour ${ }^{3}$ and Alaa Osman ${ }^{1}$ \\ 1. Zoology Department, Faculty of Science, Al-Azhar University, Assiut Branch, 71524 Assiut, Egypt \\ 2. Egyptian Environmental Affairs Agency, Natural Conservation Sector, Red Sea Protectorates, Egypt \\ 3. National Institute of Oceanography and Fisheries, Red Sea Branch, Hurghada 84511, Egypt \\ *Corresponding Author: aldoushy@azhar.edu.eg
}

\begin{tabular}{l} 
ARTICLE INFO \\
Article History: \\
Received: Jan. 19, 2021 \\
Accepted: Feb. 5, 2021 \\
Online: Feb. 17, 2021 \\
\hline Keywords: \\
Indo-Pacific Bottlenose \\
Dolphin, Tursiops \\
aduncus, Status, \\
Northern Island, \\
Hurghada, \\
Red Sea, Egypt
\end{tabular}
Bottlenose Dolphin, Tursiops aduncus Ehrenberg, 1833 (Family Delphinidae: Order Cetacea) sighting in the northern protected Islands. An exclusive study was conducted to describe the sighting of T. aduncus in the northern Red Sea. Sighting of dolphins became the most attractive ecotourism in the Red Sea, especially in Hurghada within the marine boundary of the northern protectorate. Dolphin sighting was monitored in three selected sites, located within the northern protected area (Shaab El-Fanous, Shaab El-Erg, and El-Gouna reef) during the period from July 2015 till May 2017. At the selected sites, the mean value of dolphin sighting showed a seasonal different pattern, recording a sharp peak in spring and summer (June, July and August), and a decline in autumn (October and November). The estimated mean of dolphin sighting averaged $4.9 \pm 3.6,5.1 \pm 4.9 ; 7.8 \pm 5.4$ individual/ day at Shaab El-Fanous, Shaab El-Erg and El-Gouna reef, respectively. Whereas, the mean of snorkeler/day and boats /day averaged 56 and 5; 82 and 5; 83 and 3 /day at Shaab El-Fanous, Shaab El-Erg and El-Gouna reef, respectively. The daily pattern of dolphin sighting exhibits different ones during the resting time at the study sites. At Shaab El-Fanous, the rest period extended from 8:30 am to $13: 00 \mathrm{pm}$, with a peak at 11:00 am compared to a dolphin rest period from 9:00 am to 14:00 pm, with a peak at 11:30 at Shaab El-Erg and from 9:00 am to 13:30 pm, with a peak at 11:30 am at El-Gouna reefs. The obtained results indicated that in the Red Sea from Halayeb City to Al-Zafarana City, fifteen cases of dolphin accidents were recorded (total 25 individuals) during the last seven years (2014-2021). In the Egyptian Red Sea shore, common threats encountered T. aduncus including fishing nets, shark attacks, and boat accidents. Consequently, great mortality data was determined among T. aduncus; about $88 \%$ (22 individuals).

\section{INTRODUCTION}

The Red Sea is one of the world's most significant deposits of marine biodiversity.
These marine resources, particularly coral reefs, have gained tourist interest in a way that
tourist activities are predominant along the Egyptian Red Sea coasts. Thus, tourism has
developed considerably in recent years, making a major contribution to the Egyptian

The Red Sea is one of the world's most significant deposits of marine biodiversity.
These marine resources, particularly coral reefs, have gained tourist interest in a way that
tourist activities are predominant along the Egyptian Red Sea coasts. Thus, tourism has
developed considerably in recent years, making a major contribution to the Egyptian

The Red Sea is one of the world's most significant deposits of marine biodiversity.
These marine resources, particularly coral reefs, have gained tourist interest in a way that
tourist activities are predominant along the Egyptian Red Sea coasts. Thus, tourism has
developed considerably in recent years, making a major contribution to the Egyptian

The Red Sea is one of the world's most significant deposits of marine biodiversity.
These marine resources, particularly coral reefs, have gained tourist interest in a way that
tourist activities are predominant along the Egyptian Red Sea coasts. Thus, tourism has
developed considerably in recent years, making a major contribution to the Egyptian
} 
economy (Knight, 2002). Tourism in Egypt is one of the main sources of national income as the number of tourists reached approximately 12 million during 2008/2009 (Hilmi et al., 2012).

The Red Sea is still viewed as a relatively pristine environment (PERSGA, 1998; Mahdy et al., 2018, 2021; Ghallab et al., 2020). Few investigations have been launched on marine mammals in the Red Sea. At least 17 species, including 16 cetaceans and Dugong dugong (the Sirenian), are found in the region (Frazier et al., 1987; Notarbartolo di Sciara et al., 2017). The Red Sea cetacean study began in the 1980s and was limited to a few locations along Egyptian coasts (Beadon, 1991; Notarbartolo di Sciara et al., 2009) and focused on the southern part of the Red Sea to a very limited extent (Smeenk et al., 1996; Gladstone \& Fisher, 2000). Knowledge of cetaceans is still poor in the Red Sea, particularly in the northern Red Sea protected Islands. Recently, observing Red Sea cetacean has acquired increased relevance, especially in the southern part of the region. More recently, wild dolphin sighting is an important industry in Egypt, targeting spinner dolphins and Indo-Pacific bottlenose dolphins, with local management examples (Notarbartolo di Sciara et al., 2009). In their Red List of endangered species, the IUCN labels the Indo-Pacific bottlenose dolphin as "data deficient" (Braulik et al., 2019).

The Indo-Pacific bottlenose dolphin, Tursiops aduncus (Family Delphinidae: Order Cetacea) is a species of dolphin with a length of $2.6 \mathrm{~m}$ and a weight of up to 230 $\mathrm{kg}$, marked with a dark grey back and a lighter grey or almost white belly with grey spots (Shirihai \& Jarrett, 2006). T. aduncus lives in the waters around India, northern Australia, South China, the Red Sea, and Africa's eastern coast (Reynolds et al., 2000). Until 1998, all bottlenose dolphins were considered members of the single species $T$. truncatus. During that year, the Indo-Pacific bottlenose dolphin was recognized as a separate species (Wells \& Scott, 1999). The Indo-Pacific bottlenose dolphin is generally smaller than the common bottlenose dolphin, with a proportionately longer rostrum, and spots on its belly and lower sides (Reeves et al., 2002; Wells \& Scott, 2009).Moreover, it has more teeth than the common bottlenose dolphin,which ranges from 23 to 29 teeth on each jaw side compared to 21 to 24 in the common bottlenose dolphin (Reeves et al., 2002).

The Indo-Pacific bottlenose dolphins feed on a wide variety of fish and cephalopods. By studying the stomach contents of those captured in the gillnet fisheries of Zanzibar, Tanzania, 50 species of bony fish and three species of squid among the prey items were found (Amir et al., 2005). T. aduncus lives in groups of hundreds, but groups of 5-15 dolphins are the most common (Möller \& Beheregaray, 2006). Females associate with their calves and/or other females. Mixed sex groups are frequently seen throughout the year (Ziltener \& Kreicker, 2014; Orbach et al., 2019). Maritime traffic, oil-based industrial development, chemical pollutants, fishing, disturbance, habitat 
modifications and tourism are the main human pressures on the Red Sea marine environment, particularly marine mammals (Frazier et al., 1987).

Sighting of dolphins became the most attractive ecotourism in the Red Sea; it attracts thousands of tourists to watch dolphins at Satayeh in Wadi El-Gemal national parks and Samadai reef in the Marsa Alam city (Notarbartolo di Sciara et al., 2009; Shawky et al., 2020). The wonderful biodiversity of the Red Sea marine life, however, makes Hurghada one of the best tourist destinations in the world for wild dolphin sighting by snorkeling and diving (Ziltener \& Kreicker, 2014). In recent years, swimming with wild dolphins has become a popular tourist attraction offered in the area by a range of agencies. Little is known about status of dolphin in northern Red Sea protected Islands, especially those sites characterized with dolphin sighting (Shaab El Fanous, Shaab El-Erg and El-Gouna reef). Dolphins in those sites were in danger as exposed to many boats and speed Zodiacs, snorkelers' direct touch and harassment.Among those in great danger are the highly intelligent Indo-Pacific bottlenose dolphins ( $T$. aduncus), which are very curious about divers and boats.

In recent years, dolphins in the Red Sea, especially at Hurghada, has won a great concern of some projects and societies such as: Red Sea Protectorate, HEPCA Society, Abu Salama Society and Dolphin Watch Alliance (Ziltener \& Kreicker, 2014), which, in return, increased awareness and public education. Notedly, most works about dolphins inhabiting the northern Red Sea protected Islands were just unpublished reports (Ziltener \& Kreicker, 2014; Ziltener et al., 2015) or scattering works regarding the wild dolphin parasites (Kleinertz et al., 2014). Hence, it was due to design this unique study to evaluate the status of Indo-Pacific bottlenose dolphin sighting in the protected Islands of the northern Red Sea at Hurghada. Additionally, the current study purposed to determine the daily resting behavior of the Indo-Pacific bottlenose dolphins within coral reefs, and manage the resting area in the selected sites as well.

\section{MATERIALS AND METHODS}

\subsection{Study Sites}

\subsubsection{Shaab El-Fanous:}

El-Fanous reef site is named locally Shaab El-Fanous; where Shaab means coral reefs, and El Fanous means the lighthouse found on top of the reef. This site is located at $27^{\circ} 15^{\prime \prime} 52^{\prime} \mathrm{N}$ and $33^{\circ} 53^{\prime \prime} 01^{\prime} \mathrm{E}$ in the front of Hurghada city coast, north of the Red Sea, and is $6 \mathrm{~km}$ from the new port of Hurghada Marina. The reef at this site has two sides; the one exposed to the northern reef side (the outer lagoon) and the sheltered southern reef side (the inner lagoon). The total living benthic cover of Shaab El-Fanous was 67\%. The famous diving spots are situated around this reef's eastern and western corners. The site is famous for the Indo-Pacific bottlenose dolphin sightings where many daily trips are headed to watch the dolphin (Fig. 1A, D). 


\subsubsection{Shaab El-Erg;}

Shaab El-Erg is a submerged reef that lies at the northern side of the Red Sea. It is located at $11.5 \mathrm{~km}$ from the Shedwan Island at $27^{\circ} 24^{\prime \prime} 41^{\prime} \mathrm{N}$ and $33^{\circ} 51^{\prime \prime} 16^{\prime} \mathrm{E}$. Shaab El-Erg is one of the most important diving sites in the northern side of the Red Sea. It is daily visited by safari boats for diving and snorkeling activities, due to the continuous sighting of dolphins, which is known as a dolphin house for the diving center (Fig. 1A,C). The percentage of total living benthic cover at this site was $62 \%$.

\subsubsection{El-Gouna Reef (Shaab-El-Deer):}

This site is located at $27^{\circ} 26^{\prime \prime} 4^{\prime} \mathrm{N}$ and $33^{\circ} 44^{\prime \prime} 20^{\prime} \mathrm{E}$, inside the boundary of north protected Islands, about $20 \mathrm{~km}$ north to Hurghada city. This site is very shallow, reaches about $5 \mathrm{~m}$ in depth (Fig. 1A,B). The percentage of total living benthic cover at this site was $68 \%$.

\subsection{Field Work}

During the period from July 2015 to May 2017, the speed boat (Zodiac) was used for data collection. The boat has two 200 horse machines, sometimes a small zodiac of 40 horse speed was used in calm weather conditions. Dolphin monitoring and data collection an the sites were conducted from 8 am to $3 \mathrm{pm}$ during daytime.The collected data included: recording the number of dolphins during their beginning appearance, defining the time of the dolphins entering or leaving the site and the exact GPS position of the dolphin appearance, numbers of snorkelers, numbers of boats and divers using snorkeling and Gopro underwater camera to take some picture of the recorded dolphins. The collected data were statistically analyzed using the Excel program and the resulted maps were used by the GIS program to explain the sighting distribution of dolphins at the study sites.

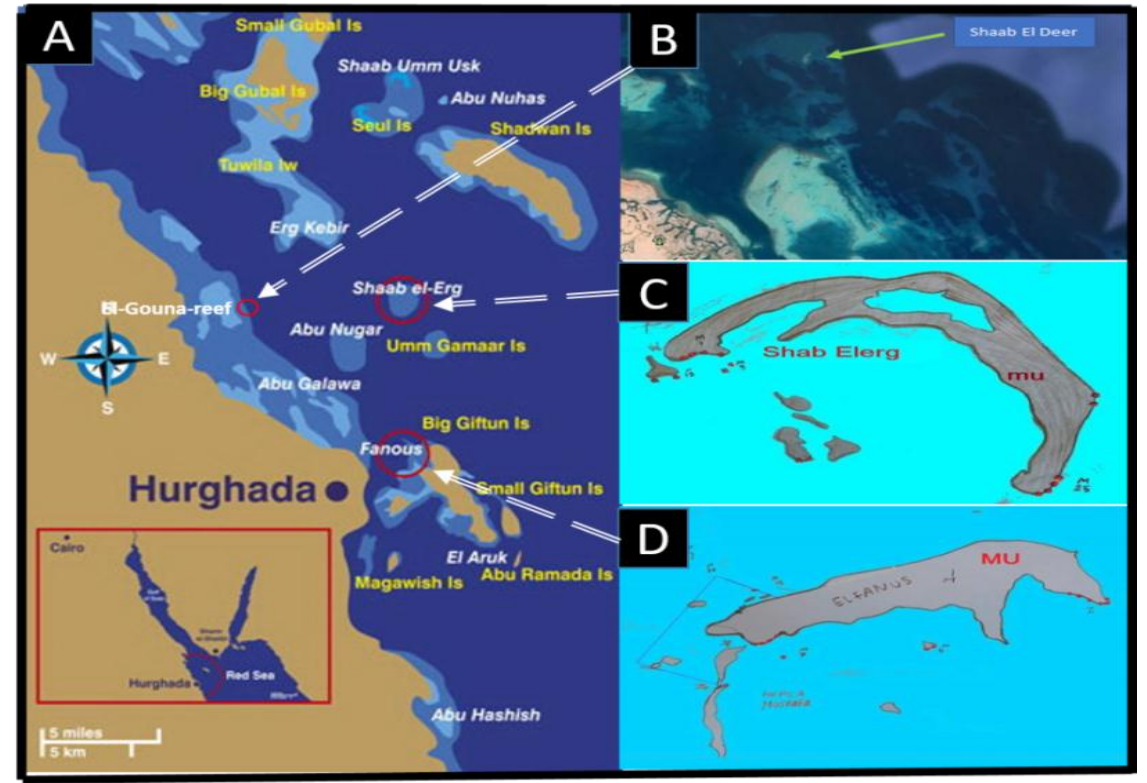

Figure (1): Maps show the study sites, (A) Red Sea northern protected Island, (B) El-Gouna Reef, (C) Shaab El-Erg, and (D) Shaab El-Fanous. 


\section{RESULTS}

\subsection{Shaab El-Fanous:}

The present results showed that, the Indo-Pacific bottlenose dolphin T. aduncus averaged 4.9 \pm 3.6 Inds./ day at Shaab El-Fanous. However, monthly variations were recorded in the average sighting at this site during the period from July 2015 to May 2017 (23 months). The numbers of the dolphin sighting in July and August 2015 and July 2016 exhibited the highest sharp peaks, but decline was witnessed in the late of autumn and winter (from October to February) (Fig. 2). The young dolphins were spotted in 8 months within the study period (23 months), recording the highest sighting in summer (July 2016) 4 individuals( Ind)/ day with total mean of $0.6 \mathrm{Ind} /$ day. Snorkelers ranged from 8 to 344 snorkelers/ day with a mean of 56 snorkelers / day. The highest boat number was 15 boats/ day in August 2015 with a mean of 5 boats/day (Fig. 2). The working day at Shaab El-Fanous fluctuated from month to the other with a mean of 7 days/month, and reached the highest (14 days) in November 2016 (Table 1).

The statistical analyses showed no significant difference in the relationship between the dolphin sightings and the number of snorkelers according to the following equation: $\mathrm{Y}=10.5 \mathrm{X}+5.0\left(\mathrm{R}^{2}=0.26\right)$, where: $\mathrm{Y}$ : is the number of snorkelers, and $\mathrm{X}$ : is the number of dolphin sighting. Also, the relation between boat numbers and dolphin sightings was non-significant and represented by the following equation: $\mathrm{Y}=0.6 \mathrm{X}+2.4$ $\left(R^{2}=0.30\right)$, where $Y$ : is the number of boats and $X:$ is the number of dolphin sightings.

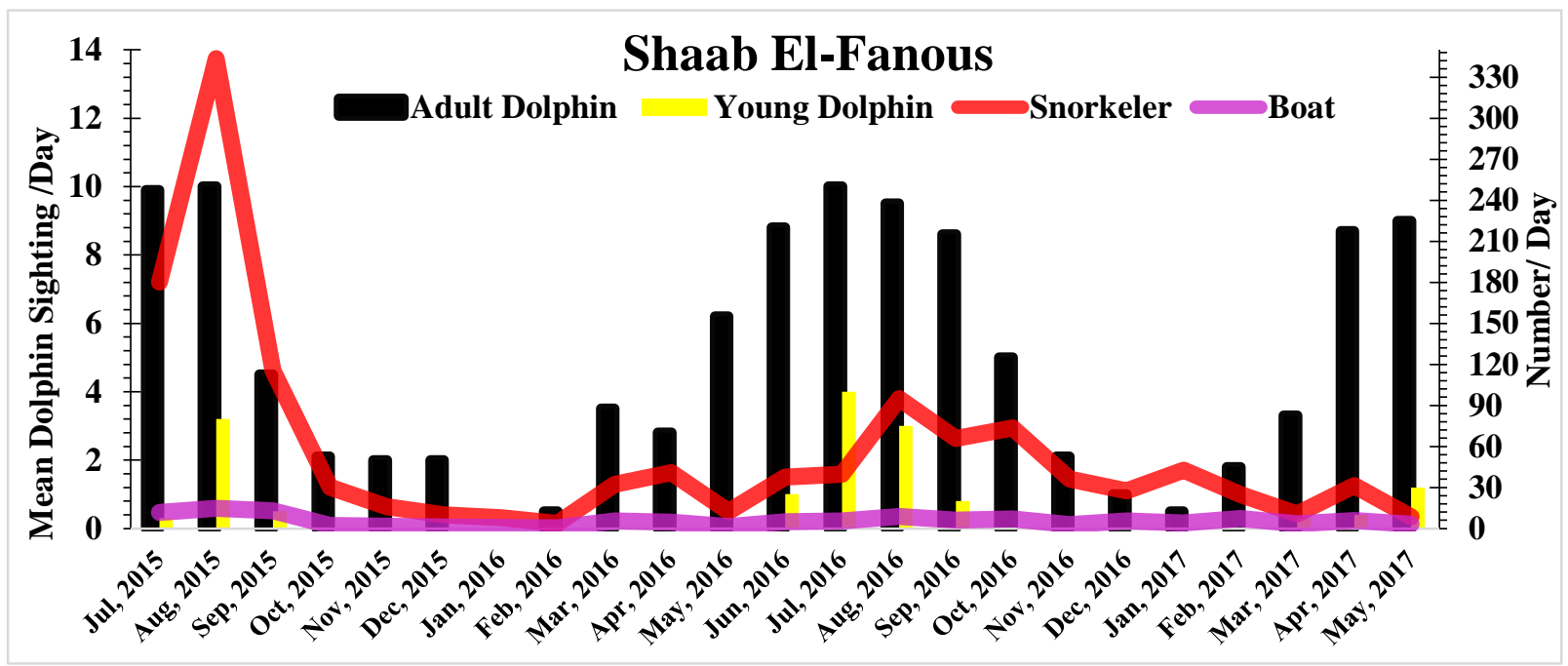

Fig. (2): Mean sighting number of Indo-Pacific bottlenose dolphin Tursiops aduncus (adult and young), snorkelers and boats in Shaab El-Fanous site. 


\subsection{Shaab El-Erg:}

The sighting figures of the dolphin show a highest peak in June 2016 with a mean of 15 Inds./day with an average of 5.1 \pm 4.9 Inds./day (Fig. 3). At Shaab El-Erg, the average working days was 3 days/month, and the highest was in December 2015 and October 2016 with 6 days/month (Table 1). The young dolphins appeared in 6 months during the study period, recording the highest number of sightings (4 Inds. /day) in summer (July 2016). The highest snorkeler's number in Shaab El-Erg was 222 snorkelers/ day, with a mean of 82 snorkelers/ day. The number of boats reached the maximum (15 boats/day) in August 2015, with an average of 5 boats/day (Fig. 3).

The analyses of recorded data showed no significant difference between the sighting of the dolphins and the number of snorkelers, and was represented by the following equation: $\mathrm{Y}=-5.3 \mathrm{X}+148.0\left(\mathrm{R}^{2}=0.43\right)$, where $\mathrm{Y}$ : is the number of snorkelers and $\mathrm{X}$ : is the number of dolphin sightings. Also, no significant difference was detected between the numbers of boats and dolphin sightings, which is represented by the following equation: $\mathrm{Y}=0.3 \mathrm{X}+3.8\left(\mathrm{R}^{2}=0.22\right)$, where $\mathrm{Y}$ : is the number of boats and $\mathrm{X}$ : is the number of dolphin sightings.

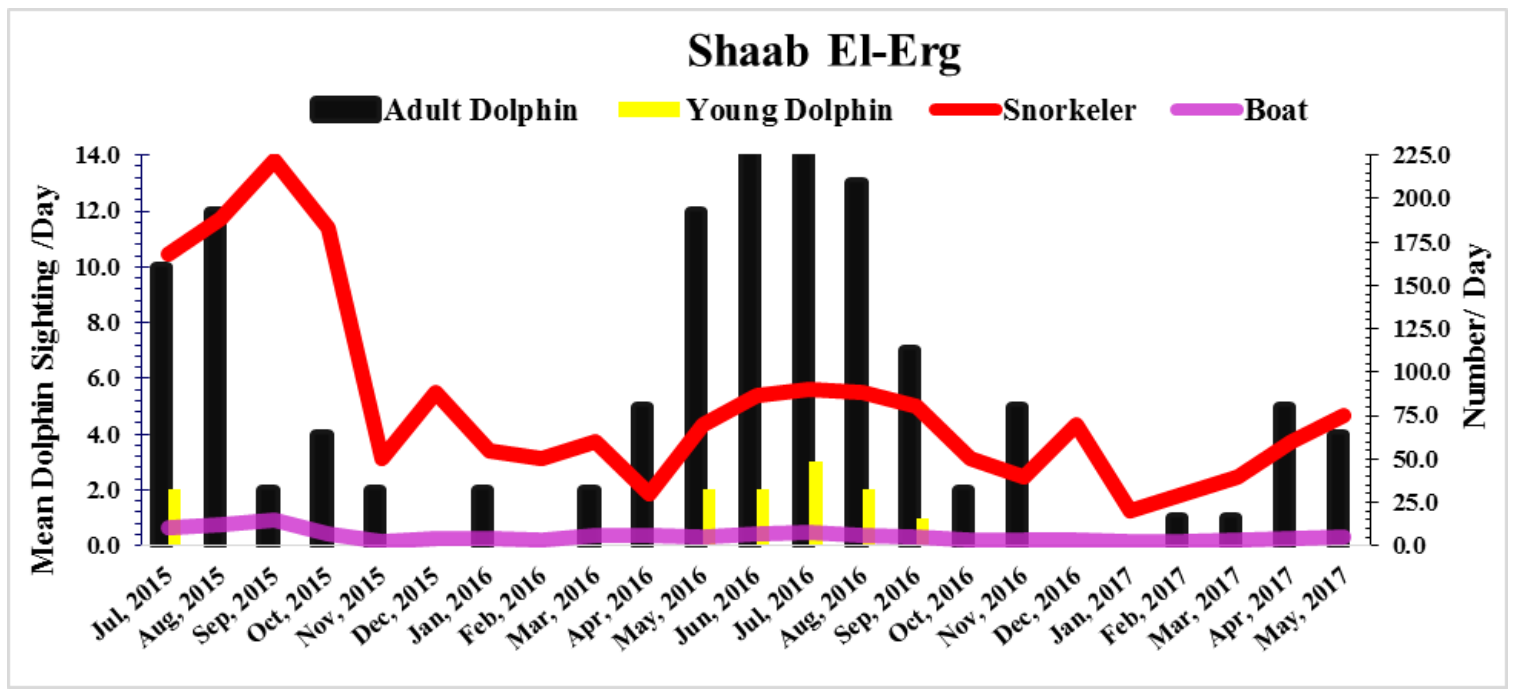

Fig. (3): Mean sighting number of Indo-Pacific bottlenose dolphin Tursiops aduncus (adult and young), snorkelers and boats in Shaab El-Erg site.

\subsection{El-Gouna Reef}

At El-Gouna reef, the results of dolphin sightings were higher than at the other two sites, with the highest number recorded in August 2015 (18 Inds./day) and an average of 7.8 \pm 5.4 Inds./day (Fig. 4). The young dolphin appeared only in one month (August 2015) with a mean of 3 individuals (Fig. 4). El-Gouna reef is one of the most remote dolphin-sighting sites, with only boats coming from El Gouna city to sight the dolphins. At El-Gouna reef, only 10 months were recorded,with working days of 4 days/ month in 
September 2015, October 2015 and November 2015, with an average of 2 days /month (Table 1). The highest snorkeler's number was 242 Snorkelers/day with a mean of 83 snorkelers/day. The highest boat number was 9 in September 2015 with a mean of 3 boats/day (Fig. 4).

No significant relationship was found between the sighting of the dolphin and the number of snorkeler, which was represented by the following equation: $\mathrm{Y}=6.0 \mathrm{X}+37.0$ $\left(\mathrm{R}^{2}=0.09\right)$, where $\mathrm{Y}$ : is the number of snorkelers and $\mathrm{X}$ : is the number of the sighting of the dolphins. Also, no significant difference was detected between the boat numbers and the sightings of the dolphin which was represented by the following equation: $\mathrm{Y}=0.20 \mathrm{X}$ $+1.5\left(\mathrm{R}^{2}=0.08\right)$, where $\mathrm{Y}$ : is the number of the boats, and $\mathrm{X}$ : is the sighting of the dolphins.

Table 1. Monthly working days of Indo-Pacific bottlenose dolphin (Tursiops aduncus) sighting at different sites from July 2015 to May 2017.

\begin{tabular}{llccc}
\hline & & \multicolumn{3}{c}{ Mean Working Days } \\
\cline { 2 - 6 } Months & Shaab El-Fanous & Shaab El-Erg & El-Gouna Reef \\
\hline 1 & Jul, 2015 & 10 & 2 & - \\
\hline 2 & Aug, 2015 & 6 & 2 & 2 \\
\hline 3 & Sep, 2015 & 4 & 3 & $\mathbf{4}$ \\
\hline 4 & Oct, 2015 & 9 & 2 & $\mathbf{4}$ \\
\hline 5 & Nov, 2015 & 5 & 5 & $\mathbf{4}$ \\
\hline 6 & Dec, 2015 & 1 & $\mathbf{6}$ & 1 \\
\hline 7 & Jan, 2016 & 4 & 3 & 1 \\
\hline 8 & Feb, 2016 & 4 & 3 & - \\
\hline 9 & Mar, 2016 & 6 & 2 & 1 \\
\hline 10 & Apr, 2016 & 11 & 2 & - \\
\hline 11 & May, 2016 & 6 & 3 & - \\
\hline 12 & Jun, 2016 & 4 & 1 & - \\
\hline 13 & Jul, 2016 & 5 & 2 & 1 \\
\hline 14 & Aug, 2016 & 8 & 5 & 1 \\
\hline 15 & Sep, 2016 & 9 & 5 & - \\
\hline 16 & Oct, 2016 & 9 & $\mathbf{6}$ & - \\
\hline 17 & Nov, 2016 & $\mathbf{1 4}$ & 3 & - \\
\hline 18 & Dec, 2016 & 5 & 1 & - \\
\hline 19 & Jan, 2017 & 8 & 1 & - \\
\hline 20 & Feb, 2017 & 9 & 2 & - \\
\hline 21 & Mar, 2017 & 12 & 4 & - \\
\hline 22 & Apr, 2017 & 6 & 4 & $\mathbf{2}$ \\
\hline 23 & May, 2017 & 5 & 3 & $\mathbf{3}$ \\
\hline & Mean & $\mathbf{7}$ & & - \\
\hline & & & 3 & \\
\hline
\end{tabular}




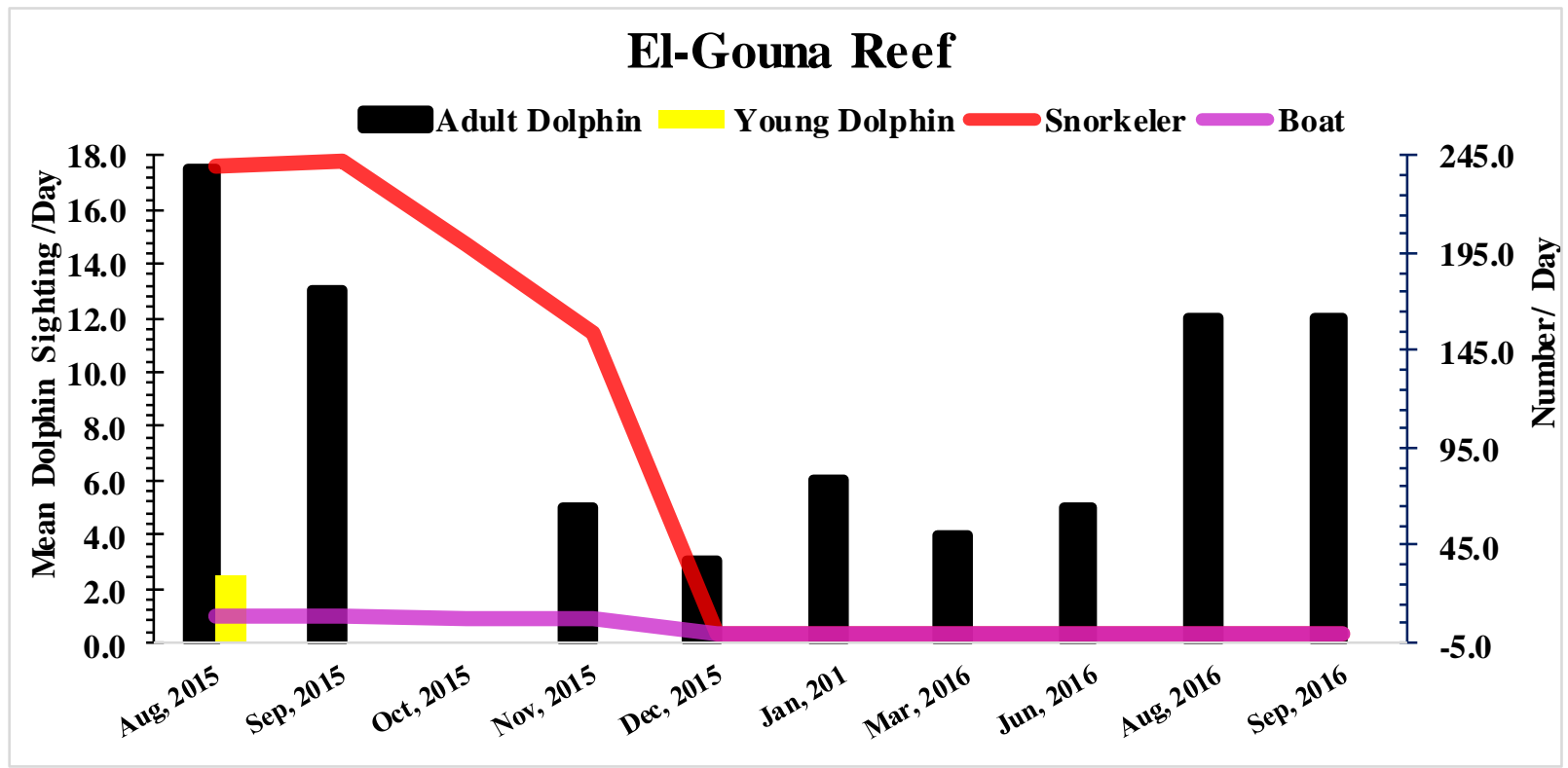

Fig. (4): Mean sighting number of Indo-Pacific bottlenose dolphin Tursiops aduncus (adult and young), snorkelers and boats in El-Gouna reef site (Shaab El-Deer).

\subsection{The Rest Time of Indo-Pacific Bottlenose Dolphin}

The study field showed that at Shaab El-Fanous dolphins appeared at 8:30 am and left at 1:30 pm, with the highest occured peak at 11:00 am (Fig. 5). Dolphins started to appear in Shaab El-Erg at 10:00 am, left at 2:00 pm, and reached the highest peak at 11:30 am (Fig. 5). The dolphin at El-Gouna reef began to appear at 9:00 am and left 1:30 pm, with a peak at 11:30 am.

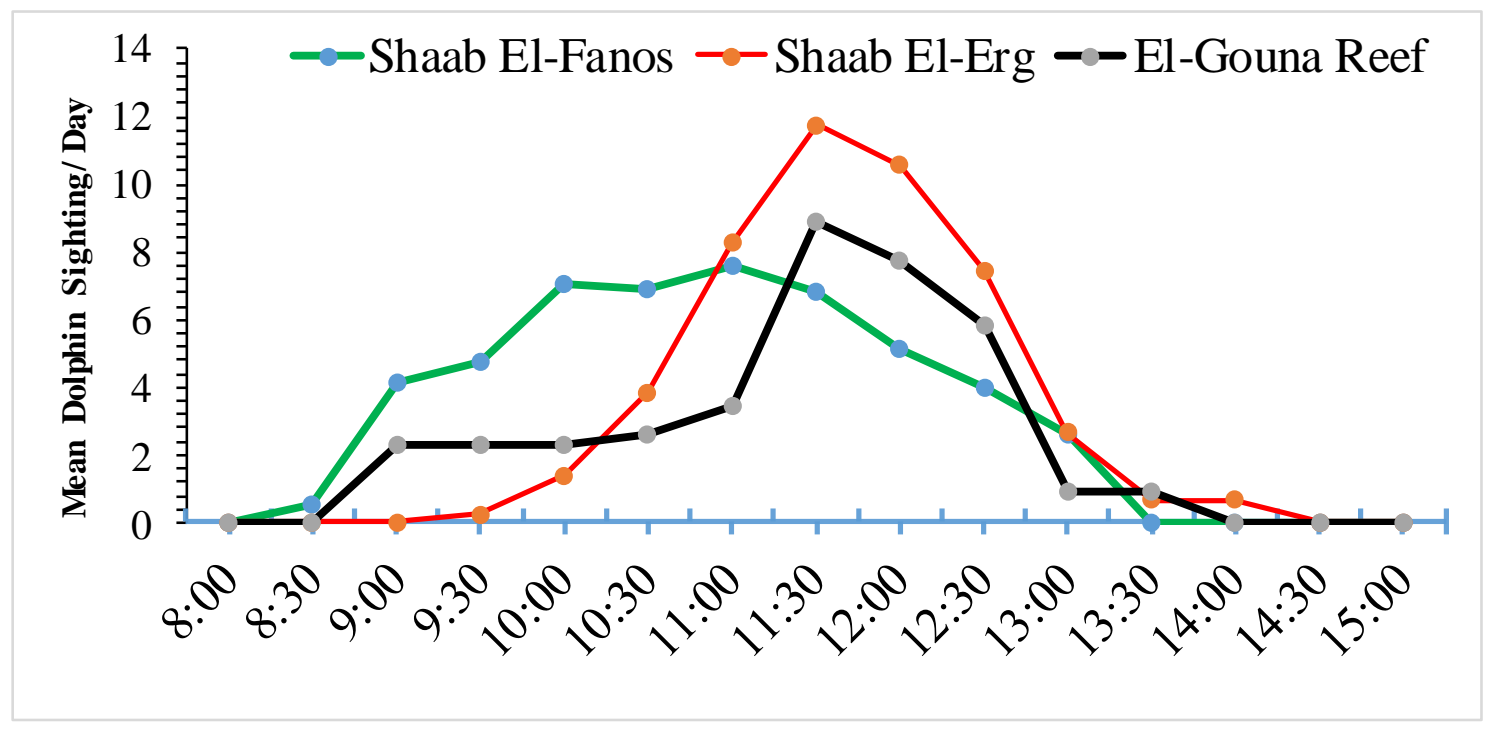

Fig. (5): The rest time of Indo-Pacific Bottle Nose dolphin sighting at Shaab El-Fanous, Shaab El-Erg and El-Gouna Reef. 


\subsection{Coordinate Sighting of Dolphin}

The GPS coordinate sighting record of T. aduncus dolphins at Shaab El-Fanous shows that more dolphins were sighted in the outer lagoon than in the inner lagoon, whereas the boat anchor was situated in the inner lagoon (Fig. 6A). On contrasts, the results of the other two sites (Shaab El-Erg and El-Gouna reef) indicated that dolphin sightings were more in the outer lagoon than in the inner lagoon (Fig.6 B, C).

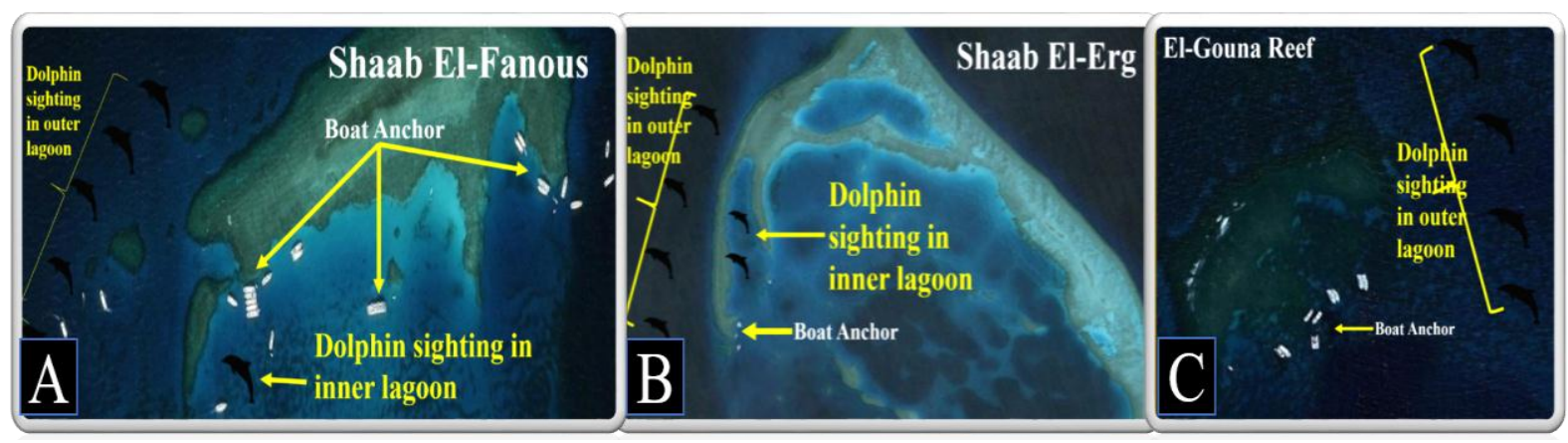

Fig. (6): Sighting place of Indo-Pacific bottlenose dolphin (Tursiops aduncus) at: A) Shaab El-Fanous, B) Shaab El-Erg, and C) El-Gouna Reef.

\subsection{Dolphin Threats and Death Accident}

At the study sites, dolphins have been suffering from distinct threats. The crowded snorkelers with dolphins at Shaab El-Fanous sets an example for the main threat at that site (Fig. 7A) in addition to the existance of speed Zodiac (Fig. 7B). At normal conditions, when no threats occur, dolphin newborn calves (first 3 months of life) were noticed swiming above the mother (Echelon position), while the young dolphins were swiming below their mother (after 3 months of life) in a baby position (Fig. 7 C, D).

In the current study, the authors collected the accidental death of dolphins, occurred in the last seven years (2014-2021) in the whole Red Sea (From Halayeb sector to Al-Zafarana shore). The obtained results indicated that, approximately 15 cases comprised 25 individuals of dolphins belong to four different dolphin species were reported dead (Table 2). In 12 cases, T. aduncus recorded a high death rate of $88 \%$ (max imum 22 dolphins) and the only one dead dolphin for the rest in each case. The reported threats included: fishing nets (4), shark attacks (4) boat accidents (3) and unknown deaths (4) (Table 2). With $44 \%$ Hurghada City recorded a high number of dolphin deaths, with 11 cases and 11 individuals (Table 2). 
Table 2. The data of dolphin death (species, number, site, record by and causing) in the Red Sea of Egypt (From Halyeb to Al-Zafarana) during the period from 2014 to 2021.

\begin{tabular}{|c|c|c|c|c|c|}
\hline Date & Dolphin & $\mathbf{N}$ & Site & Recorded By & Causing \\
\hline 18.8 .2014 & $\begin{array}{l}\text { Tursiops } \\
\text { aduncus }\end{array}$ & 1 & Gifton Island shore & HEPCA & $\begin{array}{l}\text { Dolphin was decomposed } \\
\text { and death was unknown }\end{array}$ \\
\hline 03.09 .2015 & $\begin{array}{l}\text { Tursiops } \\
\text { aduncus }\end{array}$ & 1 & NIOF shore, Hurghada & Abu Salama Society & Shark attack \\
\hline 25.06 .2016 & $\begin{array}{l}\text { Tursiops } \\
\text { aduncus }\end{array}$ & 1 & $\begin{array}{l}\text { Marsa Alam, South Red } \\
\text { Sea }\end{array}$ & $\begin{array}{l}\text { Red Sea } \\
\text { Protectorates }\end{array}$ & Shark attack \\
\hline 09.4 .2017 & $\begin{array}{l}\text { Tursiops } \\
\text { aduncus }\end{array}$ & $\overline{1}$ & $\begin{array}{l}\text { Petroleum company shore, } \\
\text { 30k north of Hurghada }\end{array}$ & $\begin{array}{l}\text { Red Sea } \\
\text { Protectorates }\end{array}$ & Shark attack \\
\hline 03.12 .2017 & $\begin{array}{l}\text { Tursiops } \\
\text { aduncus }\end{array}$ & 1 & Fanadir reef, Hurghada & $\begin{array}{l}\text { Red Sea } \\
\text { Protectorates }\end{array}$ & $\begin{array}{l}\text { Dolphin was decomposed } \\
\text { and death was unknown }\end{array}$ \\
\hline 27.02 .2017 & $\begin{array}{l}\text { Stenella } \\
\text { longirostris }\end{array}$ & 1 & $\begin{array}{l}\text { Marsa Alam, south Red } \\
\text { Sea }\end{array}$ & $\begin{array}{l}\text { Red Sea } \\
\text { Protectorates }\end{array}$ & Shark attack \\
\hline 12.2 .2018 & $\begin{array}{l}\text { Tursiops } \\
\text { aduncus }\end{array}$ & 1 & Gifton Island shore & $\begin{array}{l}\text { Red Sea } \\
\text { Protectorates }\end{array}$ & Fishing net \\
\hline 21.5 .2018 & $\begin{array}{l}\text { Stenella } \\
\text { attenuata }\end{array}$ & 1 & $50 \mathrm{~km}$ north Al-Qusier & Touristic & $\begin{array}{l}\text { Dolphin was stranded and } \\
\text { death was unknown }\end{array}$ \\
\hline 01.01 .2019 & $\begin{array}{l}\text { Tursiops } \\
\text { aduncus }\end{array}$ & 1 & $\begin{array}{l}\text { North El Gouna shore, } \\
\text { Hurghada }\end{array}$ & Abu Salama Society & Fishing net \\
\hline 27.06 .2019 & $\begin{array}{l}\text { Tursiops } \\
\text { aduncus }\end{array}$ & 1 & Hurghada shore & $\begin{array}{l}\text { Red Sea } \\
\text { Protectorates }\end{array}$ & Boat accident \\
\hline 12.02 .020 & $\begin{array}{l}\text { Pseudorca } \\
\text { crassidens }\end{array}$ & 1 & South Hurghada shore & $\begin{array}{l}\text { Red Sea } \\
\text { Protectorates }\end{array}$ & Boat accident \\
\hline 08.10 .2020 & $\begin{array}{l}\text { Tursiops } \\
\text { aduncus }\end{array}$ & 11 & Ras Banas, south Red Sea & $\begin{array}{l}\text { Red Sea } \\
\text { Protectorates }\end{array}$ & $\begin{array}{l}\text { Dolphin was stranded and } \\
\text { death was unknown }\end{array}$ \\
\hline 13.12 .2020 & $\begin{array}{l}\text { Tursiops } \\
\text { aduncus }\end{array}$ & 1 & NIOF shore, Hurghada & $\begin{array}{l}\text { Red Sea } \\
\text { Protectorates }\end{array}$ & Fishing net \\
\hline 16.12 .2020 & $\begin{array}{l}\text { Tursiops } \\
\text { aduncus }\end{array}$ & 1 & Hurghada shore & $\begin{array}{l}\text { Red Sea } \\
\text { Protectorates }\end{array}$ & Fishing net \\
\hline 27.01 .2021 & $\begin{array}{l}\text { Tursiops } \\
\text { aduncus }\end{array}$ & 1 & $\begin{array}{l}50 \mathrm{~km} \text { north Hurghada } \\
\text { shore }\end{array}$ & $\begin{array}{l}\text { NIOF+ Red Sea } \\
\text { Protectorates }\end{array}$ & Boat accident \\
\hline
\end{tabular}




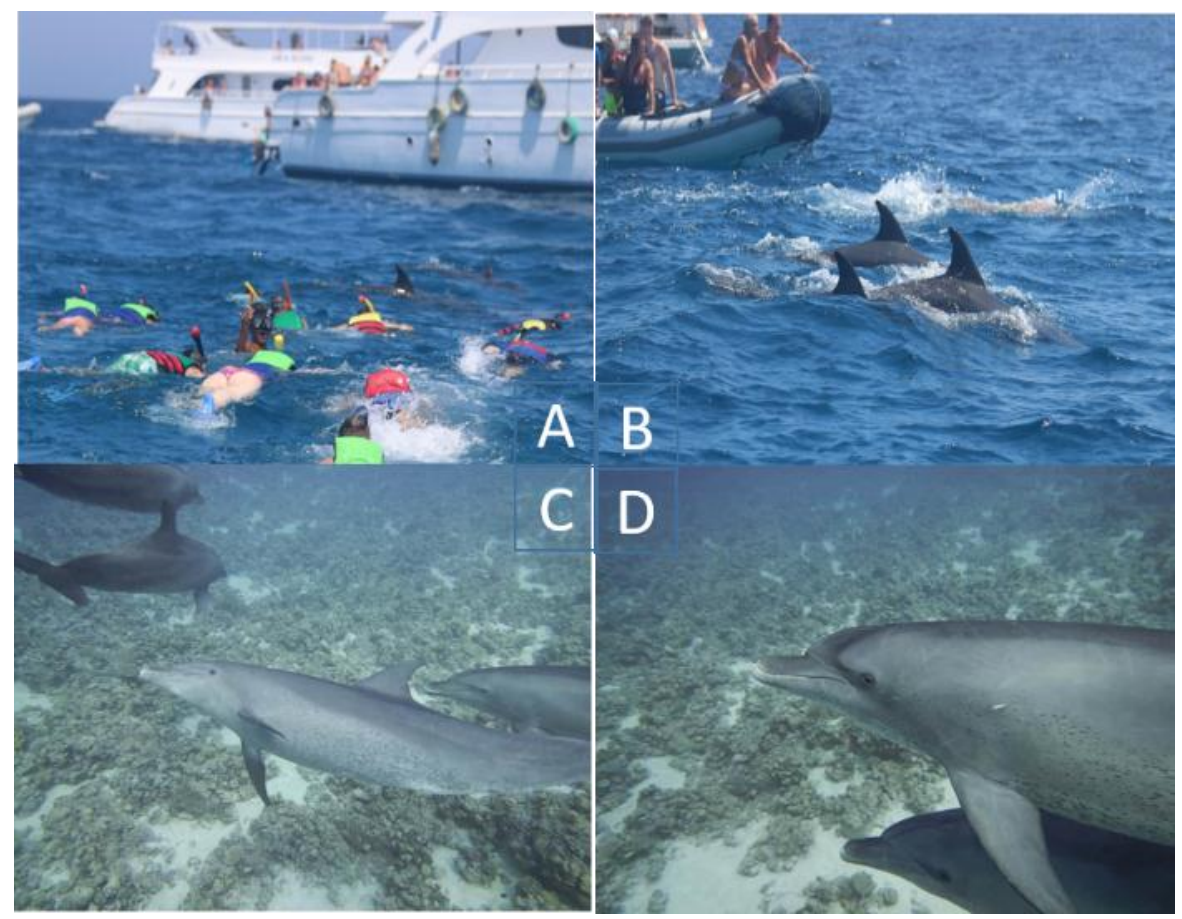

Fig. (7): Dolphin behaviour in the Shaab El-Fanous site under different environments: A) Dolphin avoiding snorkelers, B) Dolphin escaping from Zodiac, C) Dolphin Echelon Position and D) Dolphin Baby Position.

\section{DISCUSSION}

Cetacean-sighting tourism is rapidly increasing worldwide (Hoyt, 2001). Recently, snorkeling with wild dolphins, especially spinner dolphins Stenella longirostris and Indo-Pacific bottlenose dolphins T. aduncus in Egypt, has become an important industry, largely devoid of control with a high potential for the affected populations to be disrupted and extirpated (Fumagalli, 2016), in spite of the existence of local management examples (Notarbartolo di Sciara et al., 2009). Many dolphin sightings harassment have been documented in the Red Sea northern protected Islands before starting the current study.

The results of the current study at all sites indicated that, during the period from July 2015 to May 2017, T. aduncus adult and young individuals showed a different monthly sighting pattern, with highest sharp peaks in spring and summer, and a decline in late autumn and winter. Summer is the ideal time for breeding (Rice, 1998). Births can occur at any time of the year, but in warmer months peaks occur (Ziltener \& Kreicker, 2014; Kreicker \& Ziltener, 2017).

The behavior of T. aduncus Indo-Pacific bottlenose dolphin was similar to the other species of dolphins as dusky dolphin studied by Jensen et al. (2009) in Porpoise Bay, New Zealand, which are commonly sighting in summer while absent in winter. Young dolphins are born in shallow water, where only one calf is usually born, twins are 
possible, but rare (Robeck $\boldsymbol{e t}$ al., 1994). The calf sucks for 18 months up to 8 years (Robeck et al., 1994), and for several years after weaning continues to be closely associated with its mother. Thus, young dolphins were seen at the same time with adults.

In the current study, the dolphin takes its rest from 8.30 a.m. to 2:00 p.m., with its highest peak from 11:00 to 11.30 am at different studied sites. Using underwater photo identification, Ziltener and Kreicker (2014) studied the dolphin T. aduncus in the reef around Hurghada shore and identified about 250 dolphin individuals in these habitats. They also supported the present findings revealing that $T$. aduncus sleeps mainly from 8 am to $2 \mathrm{pm}$., and the dolphin rests in the shallow waters of its home range (inner or outer lagoons) to protect themselves from shark predators and anthropogenic activities. IndoPacific bottlenose dolphins are thought to seek refuges in sheltered reefs to rest in areas where they can more easily defend themselves from the hazards of shark predation. The same behaviour has been documented in Hawaiian spinner dolphin (Norris et al., 1994). At Samadai reefs, Shawky et al., (2020) showed changes in dolphin behaviour with snorkeler activities. Similar changes in dolphin behaviour were also recorded previously in other localities along the Red Sea by Ziltener et al. (2015). The dolphin remains near the surface during the sleeping cycle, swimming slowly or 'logging' and occasionally closing one eye (Lyamin et al., 2008). Moreover, the study revealed that the offshore reef habitats are particularly important for resting, including Shaab El-Fanous, Shaab ElErg and El-Gouna reef. As dolphin contacts very well with other biota; Indo-Pacific bottlenose dolphins were observed swimming with Dugong dugong (Hanafy et al., 2006; Nasr et al., 2019b). These species are extremely residential and their native range is used during their lifespan by both male and female. The data showed that Hurghada bottlenose dolphins were unique in the ecology of their species worldwide, as these dolphins forage for prey during the night and rest during the day (Ziltener et al., 2015; Kreicker \& Ziltener, 2017). Dolphins are among the few animals involved in the unusual unihemispheric sleep practice, where only half of the brain sleeps at a time (Lyamin et al., 2008).

The results of the current study showed that most days the dolphin prefers to rest on the surface outside lagoons with rare appearance in inner lagoons. This may be related to the main diving and snorkeling activities, as well as Zodiac motor noise located in the inner side of the lagoons. The resulted disturbance and noise by these activities prevent the dolphin to rest in the inner lagoon (Ziltener \& Kreicker, 2014). In Koombana Bay, Bunbury,Western Australia, Jensen et al. (2009) found the noise from Zodiac can significantly mask acoustically mediated communication and contributed the negative impact on dolphin fitness. Some dolphins were sighted in the inner lagoon at different sites during the current study, especially at Shaab El-Erg. This site was affected with the low number of boat activity, where it was remote from Hurghada shore, so the daily boat goes to Shaab El-Erg only during calm weather. 
The current study indicated that between 2014 and 2021 approximately 25 dolphin individuals died during the last 7 years, and the most significant threats were anthropogenic activities (fishing nets and boat accidents) and natural activities (shark attacks and unknown deaths). The Red Sea of Egypt lost 15 dolphin individuals during 2020, four of them died as a result of human activity (boat accident and fishing activity), eleven of them were $T$. aduncus dolphins of various ages and sexes stranded on the southern Red Sea shore. EEAA indicated that the group may have died at low tide due to water receding. The current study was the first scientific record of dolphin deaths in Egypt's Red Sea, due to its coastal habits and its highest frequency of stranding; having a high probability of interaction with coastal fisheries (Ortega-Argueta et al., 2005).

Stranding records represent an important source of information of marine megavertebrates that constitute the main attractive ecotourism, and can provide critical information to estimate the minimum level of bycatch across fisheries (Peltier $\boldsymbol{e t} \boldsymbol{a l}$., 2016). However, some of the stranding occurrences were found decomposed, which may conceal evidence of mortality associated with fisheries. The increase of stranding dolphin in the Red Sea is associated with the increase of anthropogenic activity, especially illegal fishing and dolphin sighting. Therefore, EEAA should record the stranding incident and analyze every case of death (Doukara, 2019). Thus, this place, with the high level of stress on the Indo-Pacific bottlenose dolphin in complex societies of fission-fusion, may have a direct effect on the health status of the individual and the population (Christiansen et al., 2010; Kleinertz et al., 2014).

Historically, anthropogenic activities have threatened bottlenose dolphin populations because these dolphins prefer shallow coastal waters (Braulik et al., 2019). According to the statistical findings of this study, no direct effect of snorkeling or boats number on dolphin sighting was detected. The values of $\mathrm{R}^{2}$ equal of 0.26 and 0.09 at both Shaab El-Fanous and El-Gouna reef, were, respectively, estimated. This is related to poor relationships between dolphin sighting and snorkeler in the current research. At Shaab ElErg, a good relationship $\left(\mathrm{R}^{2}=0.43\right)$ was found. At both of Shaab El-Erg $\left(\mathrm{R}^{2}=0.22\right)$ and El-Gouna reef $(\mathrm{R} 2=0.08)$ the relationships were weak as a result of the effects of boats on dolphin sightings. So far, it is hard to determine that there is a direct relationship between dolphins and swimmers, but it is known that dolphins are disturbed at rest.

\section{CONCLUSION}

As far as it is known, there is no available literature dealing with Indo-Pacific bottlenose status in the Northern Protected Islands of the Red Sea, so the present study is the first trial, investigating the status of dolphins sightings at those Islands, north Hurghada. The mean sighting of dolphins in the selected sites showed seasonal different patterns, having a sharp peak in spring and summer and a decrease in late autumn and 
winter. The results of the present work concluded that the resting time for dolphins was approximately between 8:00 am up to $2 \mathrm{pm}$. Dolphin prefers to sleep in a quiet places. According to the present results, the primary cause of dolphin death at the selected sites is attributed to human activities.

\section{RECOMENDATION}

The present study recommends carrying out researches using robust scientific methods in order to reduce the noise around marine animals. It also recommends to take speedy steps and join forces to set up a Red Sea Marine Mammal Research Center for environmental studies and awareness.

\section{ACKNOWLEDGMENT}

First of all, we would like to thank the Red Sea Protectorate Rangers, Dr. Tamer Attalah, Dr. El-Sayed Salem, Mr. Abdalla Abed, Mr. Ahmed Bakry, Mr. Islam El Sadek, Mr. Mohamed Megahed and Mr. Usama Maher, for assisting us with the data collection. Miss. Asmaa Ramdan and Mr. Waleed Ramdan are not to be forgotten for helping us with GIS maps. Finally, we thank boat captains Sayed Oda, Helmy Henedy, Mahmoud Safwat and Alaa Rashed.

\section{REFERENCES}

Amir, O.A; Jiddaw, N.S. and Berggern, P. (2005). The occurrence distribution of dolphin in Zanzibar Tanzania, with comment on the difference between two species of Tursiops. Western Indian Ocean J. Mar. Sci., 4(1): 85-93.

Beadon, J.J. (1991). A note on cetaceans seen and live-captured in the Gulf of Aqaba and the Gulf of Suez, 15 September 1980 through 1 September 1981. In: UNEP Marine Mammal Technical Report, pp. 111-14.

Braulik, G.; Natoli, A., Kiszka, J.; Parra, G.; Plön, S. and Smith, B.D. (2019). Tursiops aduncus. The IUCN Red List of Threatened Species: e.T41714A50381127. https://dx.doi.org/10.2305/IUCN.UK.2019-3.RLTS.T41714A50381127.en.

Christiansen, F.; Lusseau, D; Stensland, E and Berggren, P. (2010). Effects of tourist boats on the behaviour of Indo-Pacific bottlenose dolphins off the south coast of Zanzibar. Endanger Species Res., 11:91-99.

Doukara, K. A. (2019). A stranding record of the short beaked common dolphin (Delphinus delphis) in Algerian West Coast, during 2008-2012. Aquatic Conserv: Mar. Freshw. Ecosyst. pp. 1-7. https://doi.org/10.1002/ aqc.3207.

Frazier, J; Colin Bertman, G. and Evans, P.G. (1987). Turtles and marine mammals, Chapter 14, In: Key Environments, Red Sea. Edwards, A. J. and Head, S. M. (eds.), Pergamon Press, Oxford, pp. 288- 314.

Fumagalli, M. (2016). Conservation of spinner dolphin in the Egyptian Red Sea. Ph.D thesis, University of Otago, Dunedin, New Zealand, pp. 282. 
Ghallab, A.; Mahdy, A.; Madkour, H. and Osman, A. (2020). Distribution and Diversity of Living Natural Resources from the Most Northern Red Sea Islands, Egypt: IHard and Soft Corals Egyptian Journal of Aquatic Biology \& Fisheries, 24(5): $125-145$.

Gladstone, W. and Fisher, P.R. (2000). Status and ecology of cetaceans in the Farasan Islands Marine Protected Area (Red Sea). Fauna of Arabia, 18: 385-396.

Hanafy, M.; Gheny, M.; A.; Rouphael, A.B.; Salam, A. and Fouda, M. (2006). The Dugong, Dugong dugon, in Egyptian waters: distribution, relative abundance and threats. Zoology in the Middle East, 39(1): 17-24.

Hilmi, N.; Safa, A.; Reynaud, S. and Allemand, D. (2012). Coral Reef and Tourism in Egypt Red Sea. Topics in Middle Eastern and African Economies, 14, Pp. 20.

Hoyt, E. (2001). Whale watching 2001. Worldwide tourism numbers, expenditures and expanding socioeconomic benefits. A special report from the International Fund for Animal Welfare, pp.165.

Jensen, F.H.; Bejder, L; Wahlberg, M; Aguilar Soto, N; Johnson, M. and Madsen, P.T. (2009). Vessel noise effect on delphinid communication. Mar. Ecol. Prog. Ser., 395:161-175.

Kleinertz, S; Hermosilla, C; Ziltener, A; Kreicker, S; Hirzmann, J; Abdel-Ghaffar, F. and Taubert, A. (2014). Gastrointestinal parasites of free-living Indo-Pacific bottlenose dolphins (Tursiops aduncus) in the Northern Red Sea, Egypt. Parasitol. Res., 113:1405-1415. doi:10.1007/s00436-014-3781-4.

Knight, M. (2002), "Economic Profile of Red Sea Tourism and The Dive Industry," unpublished mimeo, Red Sea Sustainable Tourism Initiative, Ministry of Tourism, Cairo, Egypt, pp. 88.

Kreicker, S. and Ziltener, A. (2017). It's time to sleep. The structured diurnal activity pattern of Indo-Pacific bottlenose dolphins (Tursiops aduncus) around Hurghada, Egyptian Red Sea and its conservation implications. In: $22^{\text {nd }}$ Biennial Conference on the biology of marine mammals. The Society for Marine Mammalogy, Halifax, Nova Scotia, Canada, 23-27 October.

Lyamin, O.I.; Manger, P.R.; Ridgway, S.H., Mukhametov, L.M. and Siegal, J.M. (2008). Cetacean Sleep: An Unusual Form of Mammalian Sleep. Neuroscience and Biobehavioral Reviews, 32:1451-1484.

Mahdy, A.; Ghallab, A.; Madkour, H. and Osman, A. (2021). Status of Seagrass community in Northern Protected Islands, Hurghada, Red Sea, Egypt. Aqu. Sci. \& Fish Res. (2): 1-8.

Mahdy, A.; Omar H.A.; Nasser S.A.M.; Abd El-Wakeil, K.F. and Obuid-Allah, A.H. (2018). Community structure of Echinoderms in littoral zone of the Red Sea Coast of Egypt. Egyptian Journal of Aquatic Biology and Fisheries, 22 (5): 483-498. 
Möller, L.M and Beheregaray, L.B. (2006). Coastal bottlenose dolphins from southeastern Australia are Tursiops aduncus according to sequences of the mitochondrial DNA control region. Marine Mammals' Science, 17(2):249-263.

Nasr, D.; Shawky, A.M. and Vine P. (2019). Status of Red Sea Dugongs. In: Rasul N., Stewart I. (eds.) Oceanographic and Biological Aspects of the Red Sea, Springer International Publishing, Cham, Pp. 327-354, 10.1007/978-3-319-99417-8_18

Norris, K.S; Würsig, B. and Wells, R.S. (1994). Aerial behavior In Norris KS, Würsig B, Wells RS, Würsig M (eds.) with Brownlee SM, Johnson C, Solow J. The Hawaiian spinner dolphin, 103-121. University of California Press, Berkeley Los Angeles, pp. 408.

Notarbartolo di Sciara, G.; Hanafy, M.H.; Fouda, M.M.; Afifi, A. and Costa, M. (2009). Spinner dolphin (Stenella longirostris,) resting habitat in Samadai reef (Egypt, Red Sea) protected through tourism management. Journal of the Marine Biological Association of United Kingdom, 89(1): 211-216.

Notarbartolo di Sciara, G.; Kerem D.; Smeenk, C.; Rudolph, P.; Cesario, A.; Costa, M. Elasar, M.; Feingold, D.; Fumagalli, M.; Goffman, O.; Hadar, N.; Mebrathu, Y.T. and Scheinin, A. (2017). Cetaceans of the Red Sea. CMS Technical Series 33, pp. 86.

Orbach, D.N.; Keener, W.; Ziltener, A.; Packard, J. and Würsig, B. (2019). Testes size, vaginal complexity, and behavior in toothed whales (Odontocetei): Arms race or tradeoff model for dusky dolphins (Lagenorhynchus obscurus), harbor porpoises (Phocoena phocoena), and bottlenose dolphins (Tursiops spp.)?. Journal of Comparative Psychology: 133(3):359-372. doi: 10.1037/com0000162.

Ortega-Argueta, A.; Perez-Sanchez, CE; Gordillo-Morales, G.; Gordillo, O.G.; Perez, D.G. and Alafita, H. (2005). Cetacean stranding on the southwestern coast of the Gulf of Mexico. Gulf Mex. Sci., 23:179-185.

Peltier, H.; Authier, M.; Deaville, R.; Dabin, W.; Jepson, P.D.; Canneyt, O.V. and Ridoux, V. (2016). Small cetacean bycatch as estimated from stranding schemes: The common dolphin case in the northeast Atlantic. Environmental Science \& Policy, 63: 7-18. https://doi.org/10.1016/j. envsci.2016.05.004.

PERSGA, (1998). Strategic Action Programme for the Red Sea and Gulf of Aden. In: Regional Organization for the Conservation of the Environment of the Red Sea and Gulf of Aden, pp. 1-93. The International Bank for Reconstruction and Development/ THE WORLD BANK 1818 H. Street, N.W., Washington, D.C. 20433, U.S.A. pp. 114.

Reeves, R.; Stewart, B.; Clapham, P. and Powell, J. (2002). Guide to Marine Mammals of the World. pp. 362-365.

Reynolds, J.E.; Wells, R.S. and Eide, S.D. (2000) The bottlenose dolphin biology and conservation, Gainesville University Press of Florida. Pp. 289. 
Rice, D.W. (1998). Marine mammals of the world: Systematics and distribution (Special Publication). The Society of Marine Mammalogy, pp. 231.

Robeck, T.; Curry, B.; McBain, J. and Kraemer, D. (1994). Reproductive biology of the bottlenose Dolphin (Tursiops truncatus) and the potential application of advanced reproductive technologies. Journal of Zoo and Wildlife Medicine, 25(3): 321-336.

Shawky, A.M.; Christiansen, F. and Ormond, R. (2020). Effects of swim- with- dolphin tourism on the behaviour of spinner dolphins, at Samadai Reef in the Egyptian Red Sea. Aquatic Conservation: Marine and Freshwter Ecosystem, 30: 13731384. https://doi.org/10.1002/aqc.3332.

Shirihai, H. and Jarrett, B. (2006). Whales, Dolphins and Other Marine Mammals of the World. Princeton and Oxford, Princeton University Press, pp. 384.

Smeenk, C.; Addink, M.J.; Van den Berg, A.B.; Bosman, C.A.W. and Cadee, G.C. (1996). Sightings of Delphinus cf. tropicalis van Bree, 1971 in the Red Sea. Bonner Zoologische Beitrage, 46: 389-398.

Wells, R.A. and Scott, M.D. (1999). Bottlenose dolphin Tursiops truncatus (Montagu, 1821). In; Ridgway SH, Harrison R (eds) Handbook of Marine Mammals. Volume 6, the second book of dolphin and the porpoises, Academic Press, London / San Diego. Pp.137-182.

Wells, R.S. and M.D. Scott. (2009). Common bottlenose dolphin (Tursiops truncatus). In: W.F. Perrin, B. Würsig, and J.G.M. Thewissen, (eds.), Encyclopedia of Marine Mammals. Second Edition. Elsevier, Inc., San Diego, CA. Pp. 149-255.

Ziltener, A. and Kreicker, S. (2014). A proposal for dolphin conservation management around Hurghada, Red Sea. Dolphin Watching Alliance, November 2014, Hurghada, Egypt, pp. 7.

Ziltener, A.; Wright, A.J. and Kreicker, S. (2015). Sleeping behaviour in Indo-Pacific bottlenose dolphins (Tursiops aduncus) off Hurghada, Northern Red Sea, Egypt. $29^{\text {th }}$ Annual Conference, European Cetacean Society, Malta, 23-25 March. 